\title{
The Effect of L-Carnitine and Intralipid Emulsion in Acute Verapamil Cardiotoxicity in Albino Rats
}

\author{
Eglal Hassan Elawady ${ }^{1}$ and Dalia Abd Elsalam Saad ${ }^{2}$ \\ ${ }^{1}$ Department of Forensic Medicine and Clinical Toxicology, Faculty of Medicine, Ain Shams University, Cairo, Egypt. \\ 2 Department of Physiology, Faculty of Medicine, Ain Shams University, Cairo, Egypt.
}

\begin{abstract}
Calcium channel blockers (CCB) drugs poisoning continues to be deadly in severe cases despite recent advances and aggressive therapies. Clinically, this toxicity can manifest into severe cardiogenic shock that is often unresponsive to conventional calcium and supportive treatment. This study aimed to investigate the effectiveness of L-carnitine, as an essential compound in cellular energy production, and intralipid emulsion 20\% (ILE), as an adjunctive antidote used in selected critically ill poisoned patients, for the treatment of hypotension, Electrocardiogram (ECG) changes and arterial blood gases (ABG) deficits in verapamil poisoned rats, either separately or in combination. The study was conducted on 64 albino rats divided into 8 groups (each of 8 rats). The groups are: group 1 (negative control group), group 2 (Lcarnitine group), group 3 (ILE group), group4 (L-carnitine and ILE group), group 5 (verapamil group), group 6 (verapamil and L-carnitine group), group7 (verapamil and ILE group), group8 (verapamil, Lcarnitine and ILE group). All animals were subjected to measurement of blood pressure, ECG recording, as well as ABG. Results: verapamil toxicity in group 5 was manifested by significant hypotension (both systolic and diastolic), ECG derangements in the form of bradycardia, prolongation of PR and QT intervals and $A B G$ changes in the form of significant low $\left(\mathrm{pH}, \mathrm{HCO}_{3}, \mathrm{PaO}_{2}\right.$ and $\left.\mathrm{PaCO}_{2}\right)$. L-carnitine and ILE separate administration with verapamil in group 6 and group 7 respectively improved the blood pressure, heart rate, ECG and ABG parameters but they still showed statistical significant difference with both the control group and group 8, regarding (blood pressure and ECG) in group 6 and (blood pressure, ECG and $A B G$ ) in group 7. Co-administration of L-carnitine and ILE together with verapamil in group 8 showed significant improvement of all toxic parameters with insignificant difference with the control group.

In conclusion, this study proved that the combined use of L-carnitine and ILE was the most effective treatment of verapamil-induced acute cardiotoxicity. Further studies are recommended on larger scale and on clinical implication to establish more the advantageous and disadvantageous of this novel therapy. It is recommended to use this novel therapy as an additive to the usual regime and when the latter fails to correct potentially fatal cases of CCB poisonings.
\end{abstract}

\section{Introduction}

$\mathrm{C}$ alcium channel blockers $(\mathrm{CCB})$ are widely prescribed for the treatment of cardiovascular diseases and have toxicity due to overdose is a common and sometimes lifethreatening concern (Shah et al., 2012).The manifestations of toxicity are generally extensions of the drug pharmacologic and therapeutic effects and often include hypotension, bradycardia, conduction block, metabolic acidosis and myocardial depression (DeWitt and Waksman, 2004 ; Kerns, 2007).
The consequent severe cardiogenic shock, that is refractory to standard medical therapies such as IV volume expansion, gut decontamination, calcium, atropine, vasopressors and glucagon, continues to be a challenging problem (St-Onge et al., 2014).

Intravenous calcium infusion is logically indicated to overcome intracellular hypocalcemia but the benefit in overdose is unclear and may even be toxic or contraindicated as in patients on digoxin treatment (Liang et al., 2011). Also, inotropics including glucagon and vasopressors therapy often fail to improve hemodynamic status in severely poisoned patients owing 
to resistance to respond secondary to underlying pathophysiology and loading complications (Shah et al., 2012; St-Onge et al., 2013). They can increase blood pressure and heart rate, but they also increase systemic vascular resistance which may result in decreases in cardiac output and perfusion of vascular beds. The increased myocardial oxygen demand may be deleterious in the setting of hypotension and decreased coronary perfusion (Engebretsen et al., 2011).

Accordingly, given the success of some metabolic agents such as high-dose insulin euglycemia therapy in CCB toxicity (Shah et al., 2012), we focused on L-carnitine and intravenous lipid emulsion 20\% (ILE) as promising valuable treatments.

L-carnitine is a natural substance initially isolated from meat (carnus) in 1905 (Perez et al., 2011). It can be supplied by the intake of protein-rich foods, but also synthesized, as an amino acid, in human liver, kidney and brain and excreted renally (Fukami et al., 2014). In humans, $75 \%$ of the total body carnitine originates from dietary sources and the remaining $25 \%$ from endogenous synthesis (Sayed-Ahmed, 2010). It is produced from the combination of the amino acids lysine and methionine, in two optical isomeric forms, of which only the isomer L-carnitine is biologically active (Evans and Fornasini, 2003; Adachi et al., 2012)

L-carnitine has drawn attention as an adjunctive treatment for a variety of medical conditions. Among them, there is evidence that chronic daily supplementation with carnitine can improve the symptoms of intermittent claudication in peripheral vascular disease and improve exercise tolerance in both angina pectoris and congestive heart failure patients (Luo et al., 2013). In addition, L-carnitine supplementation has been reported to treat arrhythmias, increase cardiac output and exercise capacity in some clinical settings (Fukami et al., 2014). Supplemental carnitine may protect cardiac muscles against ischemia, hypoxia, and oxidative stress (Sabry et al., 2009). Moreover, carnitine has been recommended for treatment of valproic acid acute toxicity, as well as the chronic toxicities of some human immunodeficiency virus and chemotherapy agents (Scarpini et al., 1997; Rigamonti et al., 2014; Li et al., 2015).

On the other hand, ILE has a long history of use as a parenteral nutrition formulation in both adult and pediatric patients. Over the past decade, ILE also emerged as a novel antidotal treatment for iatrogenic and intentional drug poisonings (Cave and Harvey, 2014). In clinical and experimental settings, ILE has proven effective in ameliorating toxicity from several lipid soluble agents, such as clomipramine, propranolol, amiodarone, bupivacaine and haloperidol (Harvey and Cave, 2007; Harvey and Cave, 2008 ; Niiya et al., 2010 ; Shi et al., 2013; Moshiri et al., 2014)

\section{Aim of the work}

Assessment of the beneficial effects of using L-carnitine and ILE $20 \%$ separately and in combination in treating acute verapamil (one of the nondihydropyridines class of CCB)- induced cardiotoxicity in rats.

\section{Ethical considerations of the study}

-Our standards of animal care and administration met those required by applicable international laws and regulations.

-Promotion of high standard care and animal well-being at all times.

-Surgical or other painful procedures were performed with appropriate sedation to avoid distress and pain.

\section{Methodology \\ The drugs}

Verapamil (Isoptin 5): was obtained as a $2 \mathrm{ml}$ ampoule containing $5 \mathrm{mg}$ verapamil (Adco Company) and was given as a single toxic dose of $15 \mathrm{mg} / \mathrm{kg}$ according to Perez et al. (2008) slowly over 5 minutes intravenously (rat tail vein). The LD50 of IV verapamil in rats is 16 $\mathrm{mg} / \mathrm{kg}$ (Tebbutt et al., 2006).

L-carnitine: was obtained as a $5 \mathrm{ml}$ ampoule containing $1 \mathrm{gm} \mathrm{L}$-carnitine (Mepaco Company) and was given as a single bolus therapeutic dose of $50 \mathrm{mg} / \mathrm{kg}$ intravenously according to Perez et al. (2011).

Intravenous lipid emulsion (ILE): was obtained as $\mathbf{5 0 0}$ $\mathrm{ml}$ of $20 \%$ lipid emulsion (Fresenius Kabi AB, Uppsala, Sweden) and was given as a single therapeutic dose of $24.8 \mathrm{~mL} / \mathrm{kg}$ according to Perez et al. (2008) slowly over 5 minutes intravenously.

\section{Animals}

This study was carried out on 64 adult male albino rats with average weight $200 \mathrm{gm}$. Environmental conditions (e.g lighting, ventilation, temperature and caging as well as water and diet) were similar for all animals. The rats were kept in these cages for one week before starting the experimentation to be adapted for any environmental condition.

\section{Animal grouping:}

The animals were divided into 8 groups, each group was composed of 8 rats. The groups are:

Group 1: (Negative control group): the animals were kept under the same environmental conditions to demonstrate the reference basic parameters.

Group 2: L-carnitine group

Group 3: Intravenous lipid emulsion20\% (ILE) group

Group 4: (L-carnitine and ILE) group

Group 5: Verapamil group

Group 6: (Verapamil and L-carnitine) group

Group 7: (Verapamil and ILE) group

Group 8: (Verapamil, L-carnitine and ILE) group

Experimental procedure:

1. Invitro measurement of the systolic and diastolic blood pressure and heart rate (HR) by the rat tail cuff method (Gad and Chengelis, 1992) by using (Biopac NIBP200A) apparatus. Rats were placed in a warming chamber for 10 minutes prior to starting experiment in order to dilate tail veins for easier access of intravenous injection and better readings of blood pressure and HR. 
2. Electrocardiographic (ECG) tracing: the rats were first anaesthetized using intraperitoneal injection of thiopental sodium at a dose of 40 $\mathrm{mg} / \mathrm{kg}$ body weight. Then hypodermic needles were inserted under the skin in the appropriate limbs to connect the ECG wire and then ECG was recorded using lead II (Gad and Chengelis, 1992). ECG records were obtained 5 minutes following verapamil injection (to show the maximal toxic effect on ECG records), then 5 minutes later, the therapeutic drugs (L-carnitine and/or ILE) were given and another ECG records were obtained after 5 minutes (to show the maximal therapeutic response) according to repeated experimental trials (pilot study). HR and durations of (PR and QT- intervals) were measured, statistically analyzed and tabulated.

3. Then the rats were sacrificed and arterial blood samples were collected from the left ventricle by using a heparinized syringe for assessment of arterial blood gases (ABG). Arterial blood samples were analyzed for $\mathrm{pH}, \mathrm{HCO}_{3}, \mathrm{PaO}_{2}$ and $\mathrm{PaCO}_{2}$ by a blood gas analyzer (CHION DIAGNOSTIC of Biar Company).

\section{Statistical analysis}

All statistical data and significance tests were performed by using SPSS (statistical program for social science).Statistical package (SPSS Inc.) version 10. Statistical significance was determined by one way ANOVA (analysis of variance) for differences between means of different groups. Further analysis was made by least significant difference (LSD) multiple rang test to find intergroupal differences. A probability of $\mathrm{p}<0.05$ was considered statistically significant.

\section{Results}

\section{Systolic and diastolic blood pressure results:}

There was non-significant difference between the control groups (groups 1,2,3,4) when compared with each other regarding the systolic and diastolic blood pressure (Table 1).

Table (1) and fig.(1) show significant reduction in systolic and diastolic blood pressure in the verapamil toxic group (group 5) when compared with the control group.

The treatment with L-carnitine in group 6 and ILE in group 7 concomitantly with verapamil resulted in amelioration of the reduced systolic and diastolic blood pressure with significant elevation when compared to the non treated group (group 5), but they still showed significant difference when compared to the control group.

Table (1) and fig. (1) also show that the combined treatment of the verapamil poisoned rats by Lcarnitine and ILE in group 8 resulted in marked improvement with significant elevation of the systolic and diastolic blood pressure when compared with the toxic group (group 5) with insignificant difference as compared with the control group.
There was significant difference between the means in the combined treated group 8 when compared to the both single treated groups 6 and 7. L-carnitine showed superiority to ILE in improving the systolic blood pressure as there was significant difference in the means between group 6 and group 7 .

\section{ECG Results:}

There was non-significant difference between the control groups (groups 1,2,3,4) when compared with each other regarding the HR and the duration of PR and QT intervals (Table 1).

This table and figs.(2,3) show significant bradycardia and prolongation of PR and QT intervals in the verapamil group (group 5) compared to the control group.

The treated groups 6, 7 and 8 showed significant increase in the HR when compared with non treated group 5 and non-significant difference when compared with the control group or when compared with each other (Fig. 2).

There was significant correction of the prolonged PR and QT intervals in the L-carnitine treated group (group 6) as well as in the ILE treated group (group 7) as compared with the non treated group 5, yet, both groups showed significant difference when compared to the control group and non-significant difference when compared with each other (Fig. 3).

The best outcome was obtained by the combined treatment with L-carnitine and ILE in group 8 which resulted in marked amelioration of the prolonged PR and QT intervals induced by verapamil intoxication as it showed significant shortening of both intervals when compared with the toxic group 5 as well as when compared with the single treated groups (group 6 and group 7) together with non-significant difference when compared with the control group (Table 1 and fig. 3).

\section{Results of arterial blood gases (ABG):}

There was non-significant difference between the control groups (groups 1,2,3,4) when compared with each other regarding the changes in arterial blood gases (Table 2).

This table and figs. $(4,5,6)$ show significant acidosis, reduction of $\mathrm{HCO}_{3}$ and $\mathrm{PaCO}_{2}$ values, and hypoxia in the verapamil group (group 5) when compared with the control group.

The ABG changes induced by verapamil were significantly corrected by the administration of Lcarnitine and ILE, either separately in groups 6 and 7 or in combination (group 8), when compared with the non treated toxic group (group 5). However, ILE single treatment in group 7 still showed significant values as compared with the control group as well as when compared with the combined group 8.

There was non-significant difference between the treated groups 6 and 8 and each other or when compared with the control group regarding the values of the ABG (Table 2 and figs.4,5,6). 
Table (1): ANOVA one way statistical analysis showing systolic and diastolic blood pressure and ECG changes in group 1 (Control group), group2 (L-carnitine group), group 3 (ILE group), group 4 (L-carnitine and ILE group), group 5 (verapamil group), group 6 (verapamil and L-carnitine group), group 7 (verapamil and ILE group) and group 8 (verapamil, L-carnitine and ILE group). Each group contains 8 rats.

\begin{tabular}{|c|c|c|c|c|c|c|c|c|c|}
\hline $\begin{array}{l}\text { groups } \\
\text { parameter } \\
\text {-s }\end{array}$ & $\begin{array}{l}\text { Group1 } \\
\text { Mean } \pm \\
\text { SD }\end{array}$ & $\begin{array}{l}\text { Group } 2 \\
\text { Mean } \pm \\
\text { SD }\end{array}$ & $\begin{array}{l}\text { Group } 3 \\
\text { Mean } \pm \\
\text { SD }\end{array}$ & $\begin{array}{l}\text { Group } 4 \\
\underset{\text { Mean } \pm}{\text { SD }}\end{array}$ & $\begin{array}{l}\text { Group } 5 \\
\text { Mean } \pm \\
\quad \text { SD }\end{array}$ & $\begin{array}{l}\text { Group } 6 \\
\text { Mean } \pm \\
\text { SD }\end{array}$ & $\begin{array}{c}\text { Group } 7 \\
\text { Mean } \pm \\
\text { SD }\end{array}$ & $\begin{array}{l}\text { Group } 8 \\
\text { Mean } \pm \\
\text { SD }\end{array}$ & $\begin{array}{c}\begin{array}{c}\text { Statistic } \\
\text {-al } \\
\text { analysis }\end{array} \\
\text { F }\end{array}$ \\
\hline $\begin{array}{c}\text { SBP } \\
\text { mmHg }\end{array}$ & $\begin{array}{c}128.8 \pm \\
2.7^{\#}\end{array}$ & $\begin{array}{c}126.2 \pm \\
6.7^{\#}\end{array}$ & $\begin{array}{r}125.5 \pm \\
4.9^{\#}\end{array}$ & $\begin{array}{c}124.6 \pm \\
5.6\end{array}$ & $\begin{array}{c}76.8 \pm \\
7.0 *\end{array}$ & $\begin{array}{l}111.7 \pm \\
9.5 * \# \Delta\end{array}$ & $\begin{array}{c}101.6 \pm \\
6.4 * \# \Delta\end{array}$ & $\begin{array}{c}125.8 \pm \\
5 \#\end{array}$ & 65.6 \\
\hline $\begin{array}{c}\text { DBP } \\
\mathrm{mmHg}\end{array}$ & $\begin{array}{r}78.7 \pm \\
6.4^{\#} \\
\end{array}$ & $\begin{array}{r}78.6 \pm \\
8.2^{\#}\end{array}$ & $\begin{array}{r}80.0 \pm \\
7.4^{\#} \\
\end{array}$ & $\begin{array}{r}81.5 \pm \\
8.2^{\#}\end{array}$ & $\begin{array}{c}40.6 \pm \\
6.2 * \\
\end{array}$ & $\begin{array}{l}71.6 \pm \\
7.8 * \# \Delta\end{array}$ & $\begin{array}{l}70.8 \pm \\
2.6 * \# \Delta\end{array}$ & $\begin{array}{l}79 \pm \\
6.6^{\#}\end{array}$ & 30.4 \\
\hline $\begin{array}{c}\text { Heart } \\
\text { rate } \\
\text { beats/min }\end{array}$ & $\begin{array}{c}286.5 \pm \\
31.2^{\#}\end{array}$ & $\begin{array}{c}310.1 \pm \\
42.0^{\#}\end{array}$ & $\begin{array}{c}295.0 \pm \\
38.5\end{array}$ & $\begin{array}{c}293.6 \pm \\
37.2^{\#} \\
\end{array}$ & $\begin{array}{c}106.5 \pm \\
22.8 *\end{array}$ & $\begin{array}{c}260.5 \pm \\
26.3^{\#}\end{array}$ & $\begin{array}{r}258.8 \pm \\
30.8\end{array}$ & $\begin{array}{c}276.8 \pm \\
45.1{ }^{\#} \\
\end{array}$ & 27.3 \\
\hline $\begin{array}{c}\text { PR } \\
\text { interval } \\
\text { (msec) } \\
\end{array}$ & $\begin{array}{r}81.5 \pm \\
5.9 \# \\
\end{array}$ & $\begin{array}{r}82.5 \pm \\
5.4^{\#}\end{array}$ & $\begin{array}{r}83.2 \pm \\
5.8^{\#} \\
\end{array}$ & $\begin{array}{l}83 \pm \\
6.2^{\#}\end{array}$ & $\begin{array}{c}176.5 \pm \\
7.1 *\end{array}$ & $\begin{array}{c}112 \pm \\
38.5 * \# \Delta\end{array}$ & $\begin{array}{l}114.5 \pm \\
43.1 * \# \Delta\end{array}$ & $\begin{array}{c}90.5 \pm \\
6.8^{\#} \\
\end{array}$ & 18.9 \\
\hline $\begin{array}{c}\text { QT } \\
\text { interval } \\
(\mathrm{msec})\end{array}$ & $\begin{array}{c}166.2 \pm \\
45.3^{\#}\end{array}$ & $\begin{array}{l}165 \pm \\
37.4^{\#}\end{array}$ & $\begin{array}{l}160 \pm \\
48.1{ }^{\#}\end{array}$ & $\begin{array}{c}168.7 \pm \\
40.8^{\#}\end{array}$ & $\begin{array}{c}278.8 \pm \\
23.5 *\end{array}$ & $\begin{array}{c}208.8 \pm \\
13.5 * \# \Delta\end{array}$ & $\begin{array}{l}220 \pm \\
13 * \# \Delta\end{array}$ & $\begin{array}{l}170 \pm \\
43.4^{\#}\end{array}$ & 10.7 \\
\hline
\end{tabular}

ILE: intravenous lipid emulsion,SBP: systolic blood pressure, DBP: diastolic blood pressure, msec: millisecond.

min: minute. SD: standard deviation. F: Variance ratio calculated by ANOVA one way statistical analysis.

* : significant difference as compared to control group $p<0.05$

\# : significant difference as compared to group 5 (verapamil group) $p<0.05$

$\Delta$ : significant difference as compared to group 8 (verapamil, L-carnitine and ILE group) $p<0.05$

Table (2): ANOVA one way statistical analysis showing arterial blood gases changes in group 1 (Control group), group 2 (L-carnitine group), group 3 (ILE group), group 4 (L-carnitine and ILE group), group 5 (verapamil group), group 6 (verapamil and L-carnitine group), group 7 (verapamil and ILE group) and group 8 (verapamil, L-carnitine and ILE group). Each group contains 8 rats.

\begin{tabular}{|c|c|c|c|c|c|c|c|c|c|}
\hline groups & $\begin{array}{l}\text { Group1 } \\
\text { Mean } \pm \\
\text { SD }\end{array}$ & $\begin{array}{l}\text { Group } 2 \\
\text { Mean } \pm \\
\text { SD }\end{array}$ & $\begin{array}{l}\text { Group } 3 \\
\text { Mean } \pm \\
\text { SD }\end{array}$ & $\begin{array}{c}\text { Group } 4 \\
\text { Mean } \pm \\
\text { SD }\end{array}$ & $\begin{array}{l}\text { Group } 5 \\
\text { Mean } \pm \\
\text { SD }\end{array}$ & $\begin{array}{l}\text { Group } 6 \\
\text { Mean } \pm \\
\text { SD }\end{array}$ & $\begin{array}{l}\text { Group } 7 \\
\text { Mean } \pm \\
\text { SD }\end{array}$ & $\begin{array}{l}\text { Group } 8 \\
\text { Mean } \pm \\
\text { SD }\end{array}$ & $\begin{array}{c}\begin{array}{c}\text { Statisti } \\
\text {-cal } \\
\text { analysi } \\
\text {-s }\end{array} \\
\text { F }\end{array}$ \\
\hline pH & $\begin{array}{l}7.39 \pm \\
0.02\end{array}$ & $\begin{array}{l}7.39 \pm \\
0.04^{\#}\end{array}$ & $\begin{array}{l}7.40 \pm \\
0.04\end{array}$ & $\begin{array}{l}7.41 \pm \\
0.03\end{array}$ & $\begin{array}{l}7.28 \pm \\
0.03 *\end{array}$ & $\begin{array}{l}\text { 7.37士 } \\
0.02^{\#}\end{array}$ & $\begin{array}{c}7.35 \pm \\
0.03 * \# \Delta\end{array}$ & $\begin{array}{l}7.40 \pm \\
0.04^{\#}\end{array}$ & 10.4 \\
\hline $\begin{array}{c}\mathrm{HCO}_{3} \\
(\mathrm{mmol} / \mathrm{L})\end{array}$ & $\begin{array}{r}24.3 \pm \\
1.7^{\#}\end{array}$ & $\begin{array}{c}22.7 \pm \\
1.4^{\#}\end{array}$ & $\begin{array}{c}24.1 \pm \\
1.2^{\#}\end{array}$ & $\begin{array}{c}23.7 \pm \\
1.6\end{array}$ & $\begin{array}{r}17.6 \pm \\
2.1 *\end{array}$ & $\begin{array}{r}22.8 \pm \\
2.1\end{array}$ & $\begin{array}{l}21.6 \pm \\
1.4 * \# \Delta\end{array}$ & $\begin{array}{c}23.5 \pm \\
1.3\end{array}$ & 13.4 \\
\hline $\begin{array}{c}\mathrm{PaO}_{2} \\
(\mathrm{mmHg})\end{array}$ & $\begin{array}{c}89.2 \pm \\
3.4^{\#}\end{array}$ & $\begin{array}{c}87.2 \pm \\
2.7^{\#}\end{array}$ & $\begin{array}{c}85.5 \pm \\
3.1{ }^{\#}\end{array}$ & $\begin{array}{r}87.7 \pm \\
2.4^{\#}\end{array}$ & $\begin{array}{r}57.7 \pm \\
5.9 *\end{array}$ & $\begin{array}{c}82.1 \pm \\
3.6\end{array}$ & $\begin{array}{l}75.6 \pm \\
6.0 * \# \Delta\end{array}$ & $\begin{array}{c}86.2 \pm \\
4.7^{\#}\end{array}$ & 48.9 \\
\hline $\begin{array}{c}\mathrm{PaCO}_{2} \\
(\mathrm{mmHg})\end{array}$ & $\begin{array}{c}40.8 \pm \\
3.3^{\#}\end{array}$ & $\begin{array}{c}40.5 \pm \\
4.3^{\#}\end{array}$ & $\begin{array}{c}41.7 \pm \\
3.1\end{array}$ & $\begin{array}{r}43.2 \pm \\
2.1^{\#}\end{array}$ & $\begin{array}{r}30.5 \pm \\
1.6 *\end{array}$ & $\begin{array}{l}40.1 \pm \\
3.8^{\#}\end{array}$ & $\begin{array}{l}37.7 \pm \\
2.7 * \# \Delta\end{array}$ & $\begin{array}{c}41.5 \pm \\
3.5\end{array}$ & 12.2 \\
\hline
\end{tabular}

ILE: intravenous lipid emulsion, mmol: millimole ,SD: standard deviation. F : Variance ratio calculated by ANOVA one way statistical analysis.

* : significant difference as compared to control group $p<0.05$

\# : significant difference as compared to group 5 (verapamil group) $p<0.05$

$\Delta$ : significant difference as compared to group 8 (verapamil, L-carnitine and ILE group) $p<0.05$ 


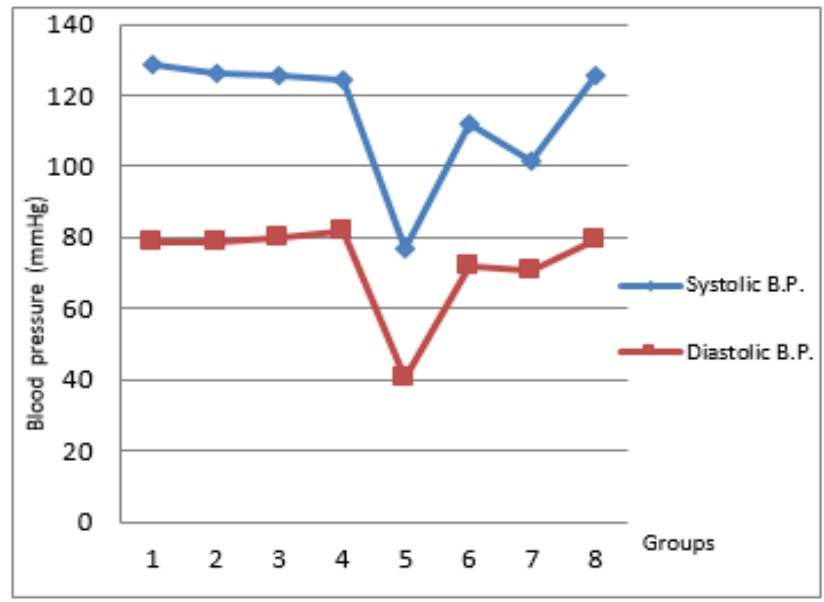

Fig. (1): Systolic and diastolic blood pressure $(\mathrm{mmHg})$ in the studied groups

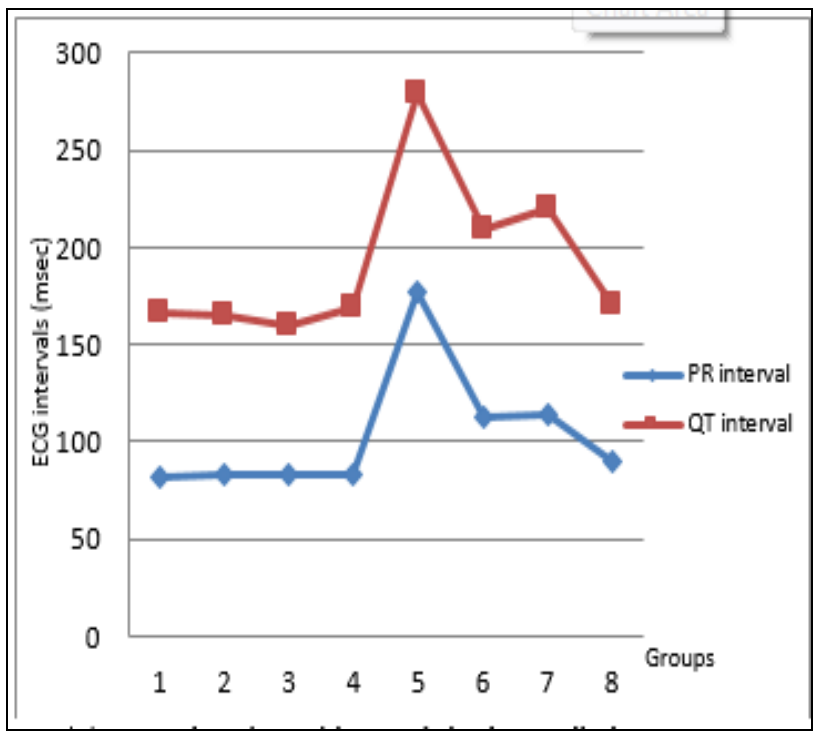

Fig. (3): PR and QT (msec) intervals in the studied groups.

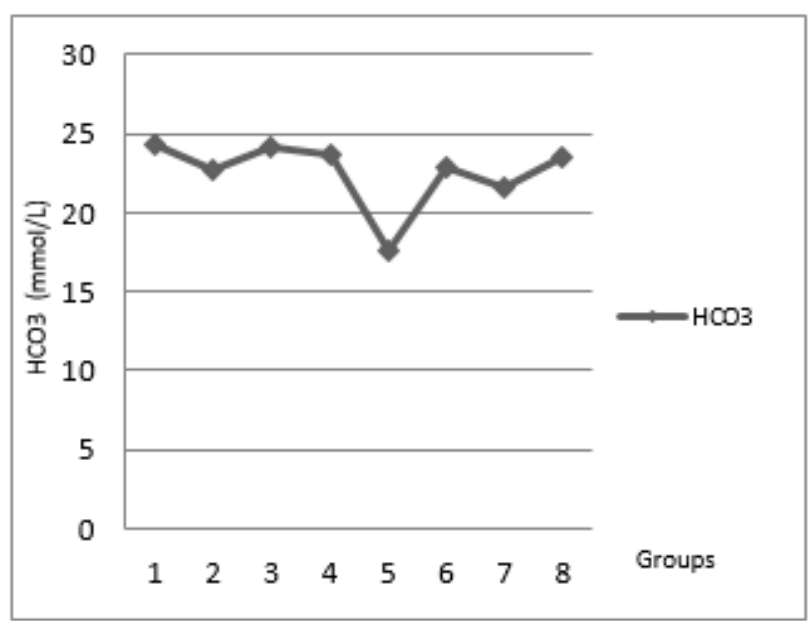

Fig. (5): HCO3 (mmol/L) levels in the studied groups

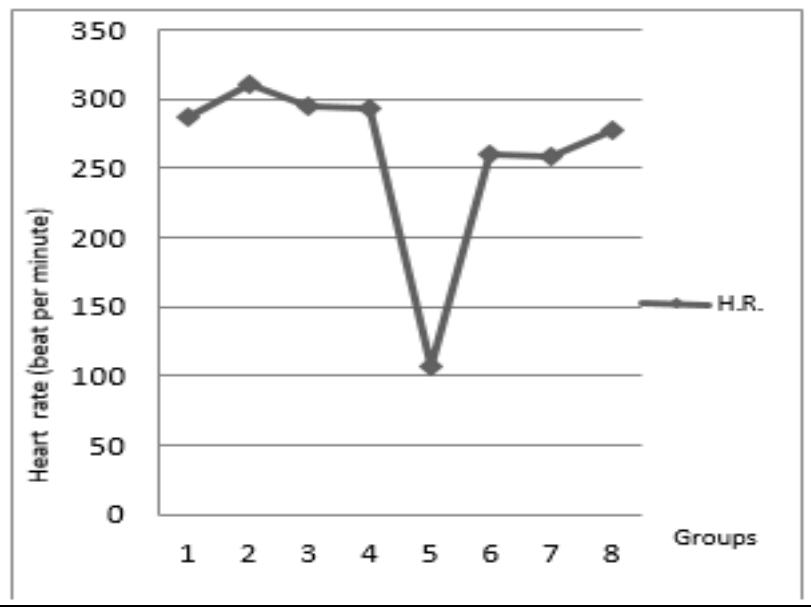

Fig. (2): Heart rate (bpm) in the studied groups.

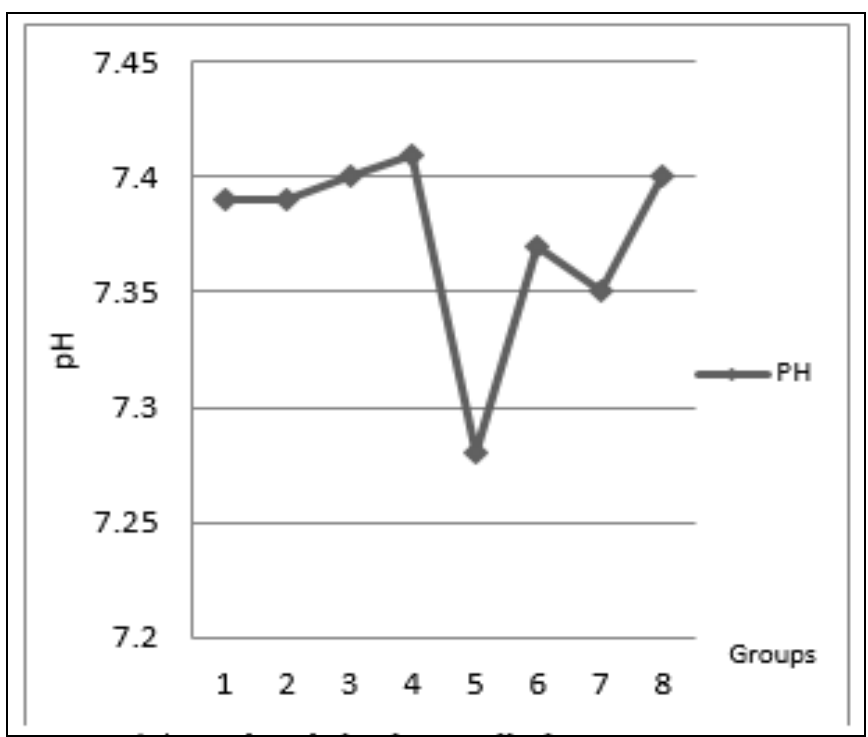

Fig. (4): pH levels in the studied groups.

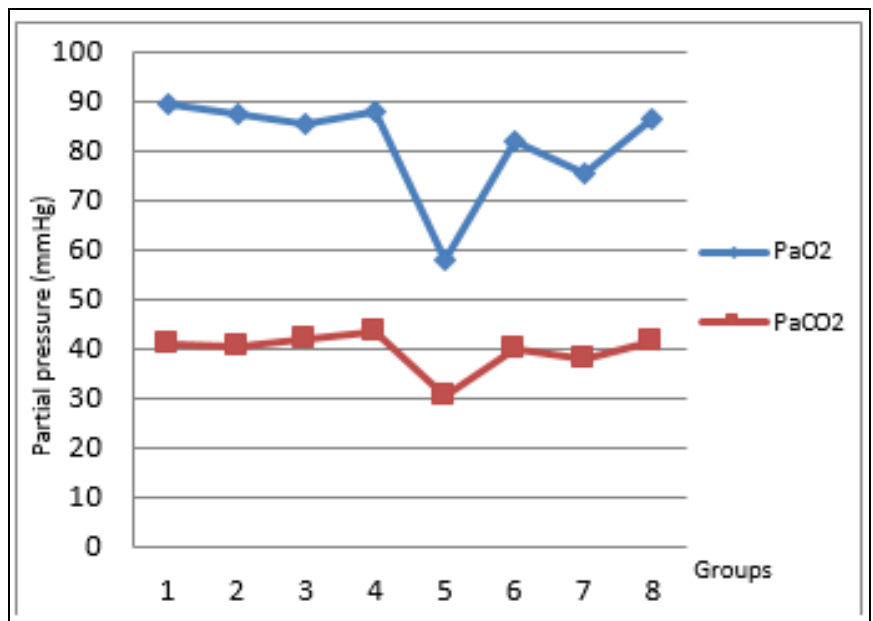

Fig. (6): $\mathrm{PaO} 2$ and $\mathrm{PaCO} 2$ (mmHg) levels in the studied groups. 


\section{Discussion}

Calcium channel blockers (CCB) poisoning continues to be deadly despite recent advances and aggressive therapies. There is no standardized treatment for significant $\mathrm{CCB}$ overdose and there is variability among clinicians as to what constitutes standard treatment especially amongst different specialties. Usually multiple agents are used in concert (Perez et al., 2011).

In this study, verapamil toxicity in group 5 was manifested by significant hypotension (both systolic and diastolic), ECG derangements in the form of bradycardia, prolongation of $\mathrm{PR}$ and $\mathrm{QT}$ intervals and $\mathrm{ABG}$ changes in the form of significant low $(\mathrm{pH}, \mathrm{HCO} 3, \mathrm{PaO} 2$ and $\mathrm{PaCO} 2)$.

Calcium channel blockers exert their therapeutic and toxic effects by the direct blockade of L-type calcium channels myocardial cells and vascular smooth muscle cells (Woodward et al., 2014). The severe hypotension in CCB toxicity results from vasodilatation and decreased cardiac output (due to bradycardia and myocardial depression). The bradycardia is often secondary to inhibition of the sinoatrial and atrioventricular nodes (Shah et al., 2012).

The resultant cardiogenic shock and the consequent metabolic acidosis are attributed to multifactorial reasons. CCB toxicity switches cardiac metabolism from free fatty acids to glucose (Woodward et al., 2014). In addition, CCB block the utilization of glucose by both inhibiting insulin release from the pancreas and inhibiting the stress-regulated entry of glucose into cells for energy consumption. Consequently, cardiac myocytes are deprived of both free fatty acids and glucose as energy sources, leading to shock (Louters et al., 2010). Hence, the effectiveness of high-dose insulin euglycemia therapy in $\mathrm{CCB}$ toxicity. By overcoming the insulin resistance, it improves glucose utilization (Woodward et al., 2014). However, failure have been reported due to insufficient dosing, delayed administration and inadequate duration (St-Onge et al., 2013), also it carries the risks of hypoglycemia and hypokalemia (Engebretsen et al., 2011).

In the present study, the administration of Lcarnitine in group 6 and intralipid emulsion 20\% (ILE) in group 7 to verapamil intoxicated rats showed significant rise in blood pressure both systolic and diastolic as well as significant improvement of bradycardia, PR and QT intervals together with significant improvement of $A B G$ indices but they still showed significant difference as compared to both the control group and group 8 (verapamil, L-carnitine and ILE), regarding [blood pressure and (PR and QT) intervals] in group 6 and [blood pressure, (PR and QT) intervals and $\mathrm{ABG}$ ] in group 7. The best outcome was gained by the concomitant use of both (L-carnitine and ILE) with verapamil in group 8 with non-significant difference as compared to the control group.
Regarding L-carnitine effect, it can be explained by many theories. First, experiments demonstrate that verapamil inhibits absorption of carnitine from the plasma into myocardial and skeletal cells (Rigault et al., 2008). Myocardial and skeletal cells do not produce their own carnitine supplies and are consequently dependent on uptake from plasma supplies generated from the liver and kidneys and to some extent absorbed from dietary supplies (Ohahi et al., 1999). It is therefore possible that L-carnitine reverses verapamil toxicity by overcoming this blockade through mass effect, resulting in intracellular carnitine levels capable of maintaining energy supplies through beta-oxidation (Perez et al., 2011).

Second possibility is that IV L-carnitine results in the direct activation of calcium channels, thereby reducing calcium channel antagonism. L-carnitine and its derivatives acylcarnitines are considered endogenous in vitro ligands for calcium channel activation that theoretically increase the activation of voltage-gated calcium channels and increase inotropy (Perez et al., 2011). This activation of myocardial calcium channels has been used to explain the positive inotropic effects of palmitoyl carnitine on chick heart cell aggregates in a study by Duncan et al. (1986).

A third explanation is that IV L-carnitine could increase free fatty acid utilization during verapamil toxicity (St-Onge et al., 2014). It is responsible for the transportation of fatty acids from the cellular cytoplasm into the mitochondrial matrix via the carnitine shuttle. Once in the mitochondria, the fatty acids undergo betaoxidation to form acetyl-CoA, which subsequently enters the Krebs cycle to satisfy cellular energy demands (Fukami et al., 2014).

One of the proposed mechanisms of verapamil toxicity is shifting cardiac metabolism from free fatty acids to carbohydrate metabolism (Bechtel et al., 2008). While IV L-carnitine shifts cardiac metabolism back to its preferential source of energy: free fatty acids, in addition to decrease insulin resistance (St-Onge et al., 2013). Thus, by supplying an energy source to the myocardium, the myocardium avoids a state of starvation and consequently contractility is maintained (Perez et al., 2011).

A potent free radicals scavenging antioxidant effect of L-carnitine, that protect tissues from oxidative damage, can add to explaining its beneficial role (Alvarez et al., 2005; Ribas et al., 2014).

Similar to this work, the cardioprotective effect of L-carnitine has been illustrated in many experimental studies of toxin induced cardiac derangement namely antimony, tilmicosin, doxorubicin and isofosfamide (Alvarez et al., 2005; Kart et al., 2007; Sayed-Ahmed, 2010; Sayed-Ahmed et al., 2014) and in a study by Perez et al. (2011), the use of L-carnitine in CCB 
poisoning increased survival and mean arterial pressure. Also, it improved cardiac function in CCB severely poisoned patient in a clinical report by St-Onge et al. (2014).

Likewise, ILE as an adjunctive antidote used in selected critically ill poisoned patients is well known to ameliorate toxicity of lipid soluble drugs (Gosselin et al., 2015), giving the fact that verapamil is a lipid soluble drug, it is possible that the mechanism for the effect of ILE is sequestration of fat-soluble toxins within an intravascular lipid compartment (Cave and Harvey, 2014). The "lipid sink" theory explains that infusion of a large amount of lipids to the blood can move the lipophilic substances away from the affected tissues and dissolve them in the plasma (Mir and Rasool, 2014).This eventually reduces free drug availability and may also enhance clearance because intralipid chylomicrons deliver compounds to the liver within the lipid phase. The latter may be especially important for agents with extensive hepatic metabolism, such as verapamil resulting in alleviation of the toxic effects (French et al., 2011).

Another possible mechanism is increasing free fatty acid availability that helps reverse the switch from lipid to glucose metabolism. Myocardial contraction is primarily driven by beta-oxidation of free fatty acids, a process which accounts for 50-70 \% of myocardial ATP production. ILE, which is composed primarily of long chain fatty acids, provides a potential source of energy for the myocardium (Carreiro et al., 2013). In addition, intralipid infusion increases b-ketoacids and nitric oxide which stimulate insulin secretion and subsequently reverse the hypoinsulinemia induced by verapamil blockade of pancreatic islet-cell L-type calcium channels and so facilitate increased carbohydrate entry into myocytes (Tebbutt et al., 2006).

Furthermore, it has been suggested that ILE may have a direct influence on calcium channels, producing a dose-dependent increase in calcium current that reverses cardiac toxicity (Gueret et al., 2007; Cave and Harvey, 2014).

Recent data have suggested that ILE at the doses used have direct cardiotonic effects (Cave and Harvey, 2014). In studies by Stehr et al. (2007), Fettiplace et al. (2013) and Fettiplace et al. (2014) ILE intake showed forceful contractions of isolated hearts of rats with increased coronary blood flow and improvement of blood pressure. It seems likely that direct cardiotonic effects play a significant role as one of the mechanisms responsible for resuscitation from drug-induced cardiotoxicity. This may be particularly so in the arrested or critically compromised circulation in order to offer immediate support before any distributive effects are likely to occur (Ozcan and Weinberg, 2014).

The results in this study regarding ILE, is in agreement with Perez et al. (2008), Cave et al. (2011) and
Doepker et al. (2014) who reported successful reversal of verapamil cardiotoxicity in several animal models and recently in some human case reports.

As regard Arterial blood gases (ABG), it has been used as a marker of perfusion in multiple shock models (Rixen et al., 2001). In this work the treatment of verapamil toxicity with both L-caritine and ILE resulted in improvement of hypoxia and acidosis which is in agreement with findings in Perez et al. (2008), Perez et al. (2011) and St-Onge et al. (2013). It is believed that an improved ABG indices with both L-carnitine and ILE treatment represents improved end-organ perfusion. This is consistent with findings in this study of increased blood pressure and HR. Also, L-carnitine and ILE may have stimulated oxidative utilization of glucose instead of converting pyruvate into lactate and contributed to decrease acidosis (Perez et al., 2008 and St-Onge et al., 2013).

This study revealed that the combination therapy in group 8 showed better outcome than single ILE administration in group7. This is in agreement with St-Onge et al. (2013) who believe that L-carnitine facilitates the metabolism of free fatty acids potentially even more so than following intravenous fat emulsion in severe CCB intoxication. Moreover, it is believed that addition of L-carnitine to ILE in total parenteral nutrition in general maintained good lipid utilization for an extended period and invalidated the increase of lactate and pyruvate that had been noticed when lipids were solely infused (Gibault et al., 1988).

\section{Conclusion}

this study proves the augmented benefits of adding Lcarnitine as a myocardial energy source, a cellular free fatty acids metabolism modulator agent, a direct calcium channel activator with subsequent inotropy, a promoter of intracellular glucose transport with ability to decrease insulin resistance, to the beneficial effect of ILE as a sequestering agent of lipophilic drugs, a free fatty acid provider, a stimulator of insulin release and a direct calcium channel activator with cardiotonic properties, in treating CCB induced carditoxicity.

The study also clarifies that the most effective treatment was L-carnitine use in combination with ILE rather than each separately.

Further studies are recommended on larger scale and on clinical implication to establish more the advantageous and disadvantageous of this novel therapy.

Comparative studies between the established treatments and this new therapy are also suggested.

It is recommended to use this novel therapy as an additive not a substitution to the usual regime and when the latter fails to correct potentially fatal cases of CCB poisonings. 


\section{Refrences}

Adachi T, Fukami K, Yamagishi $\mathrm{S}$ et al., (2012): Decreased serum carnitine is independently correlated with increased tissue accumulation levels of advanced glycation end products in haemodialysis patients. Nephrology (Carlton); 17:689-694.

Alvarez M, Malécot C, Gannier F et al., (2005): Antimony-induced cardiomyopathy in guineapig and protection by L-carnitine. $\mathrm{Br} \quad \mathrm{J}$ Pharmacol; 144(1):17-27.

Bechtel L, Haverstick D and Holstege C (2008): Verapamil toxicity dysregulates the phosphatidylinositol 3-kinase pathway. Acad Emerg Med; 15:368-74.

Carreiro S, Blum J, Jay G et al., (2013): Intravenous lipid emulsion alters the hemodynamic response to epinephrine in a rat model. Journal of Medical Toxicology ; 9: (3): 220-225.

Cave G, Harvey M and Graudins A (2011): Intravenous lipid emulsion as antidote: a summary of published human experience. Emerg Med Australas; 23(2):123-41.

Cave G and Harvey M (2014): Should we consider the infusion of lipid emulsion in the resuscitation of poisoned patients? Crit Care; 18(5):457.

DeWitt C and Waksman J (2004): Pharmacology, pathophysiology and management of calcium channel blocker and beta-blocker toxicity. Toxicol Rev; 23:223-38.

Doepker B, Healy W, Cortez E et al., (2014): High-dose insulin and intravenous lipid emulsion therapy for cardiogenic shock induced by intentional calcium-channel blocker and Beta-blocker overdose: a case series. J Emerg Med; 46(4):486-90.

Duncan G, Patmore L and Spedding M (1986): Positive ionotropic effects of palmitoyl carnitine on embryonic chick heart cell aggregates. $\mathrm{Br} \mathrm{J}$ Pharmacol; 89:757P.

Engebretsen K, Kaczmarek K, Morgan J et al., (2011): High-dose insulin therapy in beta-blocker and calcium channel-blocker poisoning. Clin Toxicol (Phila); 49:277-283.

Evans A and Fornasini G (2003): Pharmacokinetics of Lcarnitine. Clin Pharmacokinet; 42:941-967.

Fettiplace M, Akpa B, Ripper R et al., (2014): Resuscitation with lipid emulsion: dosedependent recovery from cardiac pharmacotoxicity requires a cardiotonic effect. Anesthesiology; 120:915-925.

Fettiplace M, Ripper R, Lis K et al., (2013): Rapid cardiotonic effects of lipid emulsion infusion. Crit Care Med; 41:156-162.
French D, Armenian P, Ruan W et al., (2011): Serum verapamil concentrations before and after Intralipid therapy during treatment of an overdose. Clin Toxicol (Phila); 49(4):340-4.

Fukami K, Yamagishi S, Sakai K et al., (2014): Effects of switching from oral administration to intravenous injection of L-carnitine on lipid metabolism in hemodialysis patients. Clin Kidney J; 7(5): 470-474.

Gad S and Chengelis C (1992): The rat pathology .In: Animal Models in Toxicology, Marcel Dekker Inc., NY.USA. pp: 63-66, 76-102.

Gibault J, Frey A, Guiraud M et al., (1988): Effects of Lcarnitine infusion on intralipid clearance and utilization. Study carried out in septic patients of an intensive care unit. J Parenter Enter Nutr; 12(1):29-34.

Gosselin S, Morris M, Miller-Nesbitt A et al., (2015): Methodology for AACT evidence-based recommendations on the use of intravenous lipid emulsion therapy in poisoning. Clin Toxicol (Phila); 53(6):557-64.

Gueret G, Pennec J and Arvieux C (2007): Hemodynamic effects of intralipid after verapamil intoxication may be due to a direct effect of fatty acids on myocardial calcium channels. Acad Emerg Med; 14: (8):761: 10511.

Harvey M and Cave G (2007): Intralipid outperforms sodium bicarbonate in a rabbit model of clomipramine toxicity. Ann Emerg Med; 49(2):178-85, 185.e1-4.

Harvey M and Cave G (2008): Intralipid infusion ameliorates propranolol-induced hypotension in rabbits. J Med Toxicol; 4(2):71-6.

Kart A, Yapar K, Karapehlivan M et al., (2007): The possible protective effect of L-carnitine on tilmicosin-induced cardiotoxicity in mice. Vet Med A Physiol Pathol Clin Med; 54(3):144-6.

Kerns W (2007): Management of beta adrenergic blocker and calcium channel antagonist toxicity. Emerg Med Clin North Am; 25:309-31.

Liang C, Diamond S and Hagg D (2011): Lipid rescue of massive verapamil overdose: a case report. J Med Case Reports; 5(399).

Li S, Guo J, Ying Z et al., (2015): Valproic acid-induced hepatotoxicity in Alpers syndrome is associated with mitochondrial permeability transition pore opening-dependent apoptotic sensitivity in an induced pluripotent stem cell model. Hepatology; 61(5):1730-9.

Louters L, Stehouwer N and Reckman J (2010): Verapamil inhibits the glucose transport activity of Glut-1. J Med Toxicol; 6:100-5. 
Luo T, Li J, Li L et al., (2013): A study on the efficacy and safety assessment of propionyl-L-carnitine tablets in treatment of intermittent claudication. Thromb Res; 132(4):427-32.

Mir S and Rasool R (2014): Reversal of cardiovascular toxicity in severe organophosphate poisoning with 20\% intralipid emulsion therapy: case report and review of literature. Asia Pac J Med Toxicol; 3:169-72.

Moshiri M, Vahabzadeh M, Mohammadpour A et al., (2014): Evaluation of intravenous lipid emulsion on haloperidol-induced hypotension in rabbits. Toxicol Ind Health; [Epub ahead of print].

Niiya T, Litonius E, Petäjä L et al., (2010): Intravenous lipid emulsion sequesters amiodarone in plasma and eliminates its hypotensive action in pigs. Ann Emerg Med; 56(4):402-408.e2.

Ohahi R, Tamail I, Yabuchi H et al., (1999): Na+dependent carnitine transport by organic cation transporter (OCTN2): its pharmacological and toxological relevance. J Pharmacol Exp Ther; 291:778-84

Ozcan M and Weinberg G (2014): Intravenous lipid emulsion for the treatment of drug toxicity. Journal of Intensive Care Med; 29(2):59-70.

Perez E, Bania T, Medlej K et al., (2008): Determining the optimal dose of intravenous fat emulsion for the treatment of severe verapamil toxicity in a rodent model. Acad Emerg Med; 15: (12): 1284-1289.

Perez E, Chu J, Bania T et al., (2011): L-Carnitine increases survival in a murine model of severe verapamil toxicity. Acad Emerg Med; 18:11361140.

Ribas G, Vargas C and Wajner M (2014): L-carnitine supplementation as a potential antioxidant therapy for inherited neurometabolic disorders. Gene; 533(2):469-76.

Rigamonti A, Lauria G, Grimod G et al., (2014): Valproate induced hyperammonemic encephalopathy successfully treated with levocarnitine. J Clin Neurosci; 21(4):690-1.

Rigault C, Dias V, Demarqouy J et al., (2008): Characteristics of L-carnitine import into heart cells. Biochimie; 90:5426.

Rixen D, Raum M, Holzgraefe B et al., (2001): A pig hemorrhagic shock model: oxygen debt and metabolic acidemia as indicators of severity. Shock; 16:239-44.
Sabry A, Ghaith O, Medhat T et al., (2009): Is there a role for oral L-carnitine therapy in anemia and cardiac dysfunction management in egyptian patients on maintenance hemodialysis? Eur J Gen Med; 6(2):60-68.

Sayed-Ahmed M (2010): Role of carnitine in cancer chemotherapy-induced multiple organ toxicity. Saudi Pharm J; 18(4): 195-206.

Sayed-Ahmed M, Aldelemy M, Al-Shabanah O et al., (2014): Inhibition of gene expression of carnitine palmitoyltransferase I and heart fatty acid binding protein in cyclophosphamide and ifosfamide-induced acute cardiotoxic rat models. Cardiovasc. Toxicol; 14(3):232-42.

Scarpini E, Sacilotto G, Baron P et al., (1997): Effect of acety-L-carnitine in the treatment of painful peripheral neuropathies in $\mathrm{HIV}+$ patients. J Peripher Nerv Syst; 2:250-2.

Shah S, Goswami S, Babu R et al., (2012): Management of calcium channel antagonist overdose with hyperinsulinemia-euglycemia therapy: case series and review of the literature. Case Reports in Critical Care. Volume 2012; Article ID $927040,5 \mathrm{p}$.

Shi K, Xia Y, Wang Q et al., (2013): The effect of lipid emulsion on pharmacokinetics and tissue distribution of bupivacaine in rats. Anesth Analg; 116(4):804-9.

Stehr S, Ziegeler J, Pexa A et al., (2007): The effects of lipid infusion on myocardial function and bioenergetics in 1-bupivacaine toxicity in the isolated rat heart. Anesth Analg;104:186-192.

St-Onge M, Ajmo I, Poirier D et al., (2013): L-carnitine for the treatment of a calcium channel blocker and metformin poisoning. J Med Toxicol; 9(3): 266-269.

St-Onge M, Dubé P, Gosselin S et al., (2014): Treatment for calcium channel blocker poisoning: a systematic review. Clin Toxicol (Phila); 52: (9): 926.

Tebbutt S, Harvey M, Nicholson T et al., (2006): Intralipid prolongs survival in a rat model of verapamil toxicity. Academic Emergency Medicine; 13:134-139.

Woodward C, Pourmand A and Mazer-Amirshahi M (2014): High dose insulin therapy, an evidence based approach to beta blocker/calcium channel blocker toxicity. DARU Journal of Pharmaceutical Sciences; 22:36. 


\section{الملخص العربي}

تأثير الإل- كارنيتين و مستحلب الإنتراليبيد على السمية القلبية الحادة للفيراباميل فى الجرذان البيضاء

\section{إجلال حسن العوضي ا و داليا عبد السلام سعدr}

يستمر التسمم بعقاقير مغلقات قنوات الكالسيوم في ان يكون قاتلا في الحالات الشديده على الرغم من التطورات الحديثه والعلاجات

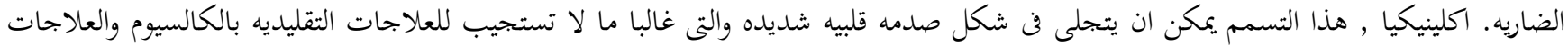

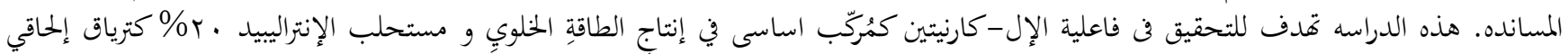

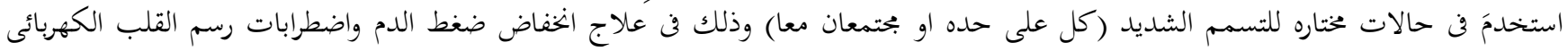

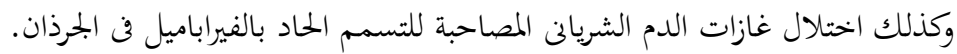

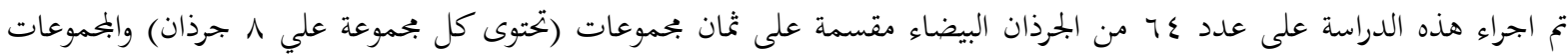

البحموعة الاولى : بحموعة ضابطة سلبية والبحموعة الثانية: اعطيت الإل -كارنيتين والمجموعة الثالثة: أعطيت مستحلب الإنتراليبيد والبحموعة

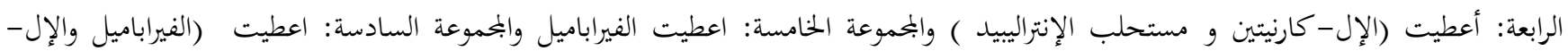

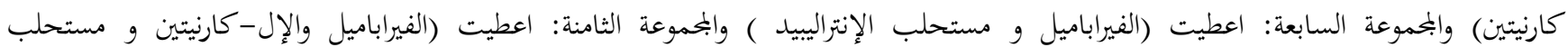

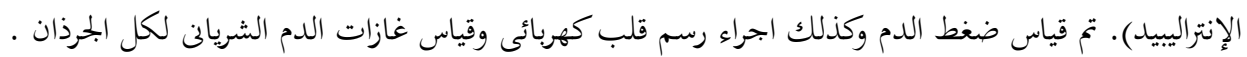

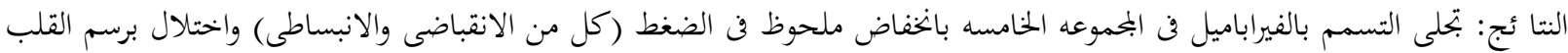

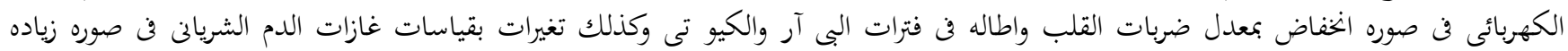

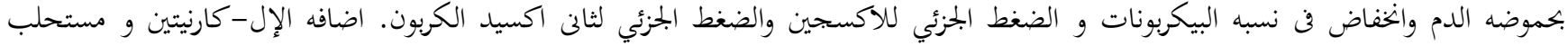

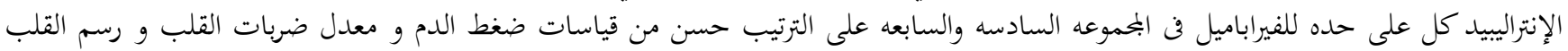

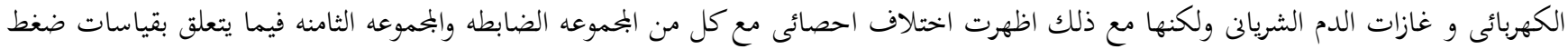

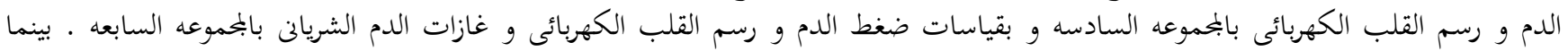

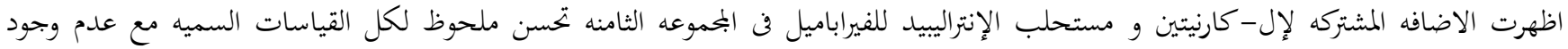
اختلاف مع البحموعه الضابطه. أنتتت هذه الدراسة أن استخدام الإل -كارنيتين مع مستحلب الإنتراليبيد كان الأكثر فاعلية في علاج السمية القلبية الحادة النابتة عن عقار الفيراباميل. وعليه فانه يوصى باجراء مزيد من الدراسات على نطاق اوسع وبتطبيق اكلينيكى لتحديد مميزات وعيوب هذا العلاج المبتكر. كما ينصح باستخدام هذا العلاج الجحيد كاضافه للنظام المعتاد وكذلك عند فشل الاخير في تصحيح حالات التسمم بمغلقات قنوات الكالسيوم المحتمل ان تكون ميتة. 